\title{
Petrochemical Economics
}

Technology Selection in a Carbon Constrained World 


\section{CATALYTIC SCIENCE SERIES}

Series Editor: Graham J. Hutchings (Cardiff University)

\section{Published}

Vol. 1 Environmental Catalysis

edited by F. J. J. G. Janssen and R. A. van Santen

Vol. 2 Catalysis by Ceria and Related Materials

edited by A. Trovarelli

Vol. 3 Zeolites for Cleaner Technologies

edited by M. Guisnet and J.-P. Gilson

Vol. 4 Isotopes in Heterogeneous Catalysis

edited by Justin S. J. Hargreaves, S. D. Jackson and G. Webb

Vol. 5 Supported Metals in Catalysis

edited by J. A. Anderson and M. F. García

Vol. 6 Catalysis by Gold

edited by G. C. Bond, C. Louis and D. T. Thompson

Vol. 7 Combinatorial Development of Solid Catalytic Materials:

Design of High-Throughput Experiments, Data Analysis,

Data Mining

edited by M. Baerns and M. Holeña

Vol. 8 Petrochemical Economics: Technology Selection in a Carbon Constrained World by D. Seddon 


\section{Petrochemical Economics}

\section{Technology Selection in a Carbon Constrained World}

\section{Duncan Seddon}

Duncan Seddon \& Associates Pty Ltd, Australia 
Published by

Imperial College Press

57 Shelton Street

Covent Garden

London WC2H 9HE

\section{Distributed by}

World Scientific Publishing Co. Pte. Ltd.

5 Toh Tuck Link, Singapore 596224

USA office: 27 Warren Street, Suite 401-402, Hackensack, NJ 07601

UK office: 57 Shelton Street, Covent Garden, London WC2H 9HE

\section{British Library Cataloguing-in-Publication Data}

A catalogue record for this book is available from the British Library.

\section{Catalytic Science Series - Vol. 8 \\ PETROCHEMICAL ECONOMICS \\ Technology Selection in a Carbon Constrained World}

Copyright () 2010 by Imperial College Press

All rights reserved. This book, or parts thereof, may not be reproduced in any form or by any means, electronic or mechanical, including photocopying, recording or any information storage and retrieval system now known or to be invented, without written permission from the Publisher.

For photocopying of material in this volume, please pay a copying fee through the Copyright Clearance Center, Inc., 222 Rosewood Drive, Danvers, MA 01923, USA. In this case permission to photocopy is not required from the publisher.

ISBN-13 978-1-84816-534-2

ISBN-10 1-84816-534-X

Disclaimer. The materials and opinions herein are based upon publicly available information believed to be reliable, and may change without notice. The author or Publisher shall not in any way be liable for claims relating to them, and makes no express or implied representations or warranties as to their accuracy or completeness or for statements or errors contained in, or omissions from, them. The information and analyses contained herein are not intended as tax, legal or investment advice and may not be suitable for your specific circumstances; accordingly, you should consult your own tax, legal, investment or other advisors to determine such suitability. Any investment returns, past, hypothetical or otherwise, are not indicative of future performance.

Printed in Singapore. 


\section{To Joan \& George}


This page intentionally left blank 


\section{PREFACE}

The objective of this book is to give industry professionals, engineering, research scientists and financiers an overview of the technologies and economics for the production of olefins in the petrochemical industries. The book gives an overview of the options and costs for producing olefins using different technologies and from different feedstocks at a time when the cost of carbon dioxide emissions are set to be included in the processing cost.

The book is based on a series of workshops and specialist seminars given by the author dating from 1996 in Singapore and Kuala Lumpur. The workshops focussed on production economics, improving plant profitability, feedstock supply and cost. The book is an updated and expanded version of the author's workshop notes.

The book critically compares the alternatives so that the most attractive options for petrochemical production can be identified for specific locations and conditions. For this purpose, technology capital and operating costs have been compared on the same basis (US Gulf location to a late 2007 cost base). From this, the production costs are estimated for various feedstock prices and compared to the traded prices of the products where appropriate.

The contents are widely embracing as possible for viable technologies in 2008. From time to time new technologies are identified or more information on emerging technologies become available. For brevity, the book does not cover technology still in the research and development stage. In particular, the extensive volume of material on the direct conversion of gas (methane) into ethylene has been omitted.

The text is roughly divided into two parts: the first six chapters discuss steam cracking technology and the approaches to olefin 
production from hydrocarbons and the later chapters concentrate on the production economics.

\section{Units}

A technical and economic appraisal of petrochemicals spans several large subject areas: petroleum and oil industry economics, petrochemical refining and applied chemistry, chemical engineering and process economics. Unfortunately these distinct fields carry their own units. The petroleum industry generally uses American units based on standards defined at $60^{\circ}$ Fahrenheit and are generally the units used in the US chemicals industry. Most chemists and academic engineers use S.I. units which are the most widely used units used in the European chemical industry. However, much petroleum engineering and refining technology uses a bastardised version - often mixing American and S.I. units in the same function.

The book generally employs S.I. units which the author considers to be the most widely acceptable. American units are used where appropriate. All costs are in US dollars of late 2007. Note the possibility of confusing US one thousand (M) with the S.I. Mega (M). In this work $\mathrm{Mt}$ is million metric tonnes and MM\$ is million US dollars.

\section{Economic Analysis}

The economic analysis follows the methodology described by the International Energy Agency for evaluating alternative feed stocks for the production of petrochemicals. Full details of the method are given in the Appendix. In summary the issue is that petrochemical technologies are highly capital intensive and some means has to be found for comparing alternatives. The method used for technology comparisons is to develop a fixed variable equation for a hypothetical green-field plant producing olefins from a given feedstock. The fixed costs of the plant are derived from published estimates of the costs of the capital items and operating costs. The operating costs can often be approximated as fixed percentages (typically 10\%) of the total installed capital cost. The return 
on working capital is also included in the fixed cost term. No account is taken of tax, depreciation or allowances.

This leaves the feedstock as the only variable in the fixed-variable equation:

$$
\mathrm{P}=\mathrm{x} . \mathrm{F}+\mathrm{C}
$$

where $\mathrm{P}$ is the product production cost, $\mathrm{F}$ is the feedstock price, $\mathrm{x}$ is the variable constant and $\mathrm{C}$ is the constant representing the fixed costs of capital and non feedstock operating costs.

The largest component of the constant $\mathrm{C}$ is the return on investment of the fixed capital. In order to make comparisons easier, a standardised methodology is adopted which is detailed in the Appendix. Typically process plants are assumed to take a similar (3 year) construction period to operate at full output over the project lifetime with zero residual value. The capital payback is then over this operating life.

Once the fixed variable relationships are derived the equation can be used to estimate the production cost for any given feedstock price. By comparing the estimated production cost with traded prices for the product, the viability of a particular project can be determined. By considering alternative technologies at similar feedstock prices, alternative approaches can be critically compared.

\section{Approximations to the Economic Analysis}

Reference is made to figure the Figure A below. ${ }^{1}$ This figure illustrates the cost error for any given project as the project proceeds to completion. The error plus or minus is the error from the final cost which is only known after the project is complete.

The first stage in the project is the concept study. This involves minimal expenditure in terms of the total project cost. The error in the cost estimate ranges from about $+/-25 \%$ to $+/-40 \%$ of the final project cost. The primary aim of this work is to improve the approach to the concept study to achieve an error in the lower end of this range. For many occasions (e.g. for very remote or unusual locations) this may not be feasible and the errors may be as much as $100 \%$ or more. 


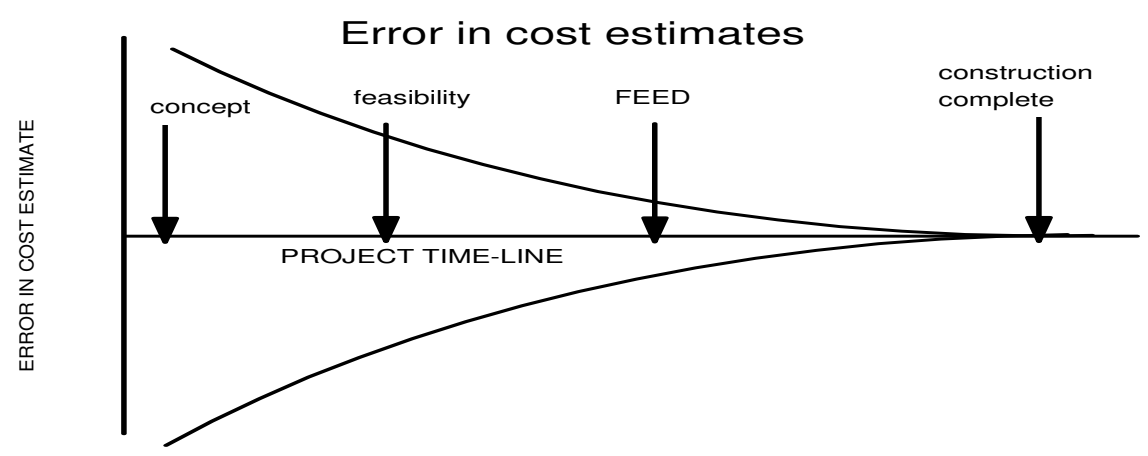

Figure A: Error in an estimate as a function of project life

The second phase is the feasibility study. This stage may require the expenditure of 1 to $2 \%$ of the total project cost. Thus for a $\$ 1,000$ million project about $\$ 20$ million will be required. This will define the location, feedstock and product market and the technology to be used. It will also typically encompass outline regulatory approval and assessment of environmental impacts. The error in the estimate is typically not less than about $+/-10 \%$. Financiers (bankers and corporate boards) like the error to be $+/-5 \%$. This level of estimate can usually only be achieved by a FEED study.

Front-End Engineering and Design (FEED) focuses on obtaining accurate cost estimates for the major items of process equipment and further definition of the most sensitive parts of the overall project cost. It is denoted Front-End because this is performed prior to final corporate board and financial approval for the overall project. FEED costs typically 5 to $10 \%$ of the overall project cost - thus for a $\$ 1,000$ million project expenditure of about $\$ 100$ million will be required. Only after the feasibility and FEED will the cost error be in the vicinity of $+/-5 \%$. In many instances, especially for new technology or for a remote location or offshore, the error will still be in the region of $+/-10 \%$ or more.

The full engineering design, procurement and construction will also account for some error, hopefully $<5 \%$. Only when the project is completed and started and running to the design specifications is the final cost of the project known. 
As the adage goes, "the accuracy of the cost estimate is proportional to the time and money expended." Unfortunately there is a common tendency to try to shorten or circumvent the costing process, which often leads to project failure.

\section{Data Sources}

The world petrochemical industry is surveyed annually in the Oil \& Gas Journal as the "Ethylene Report." This is a useful source of country production, individual steam crackers (including ownership) and the feedstock used. Since 2006 US olefins and the US natural gas liquid supply and prices are each reviewed twice per year by Lippe. Weissermel and $\mathrm{Arpe}^{3}$ have provided an excellent description of many technologies and approaches to chemical synthesis in the chemical process industry.

In this book, wherever possible literature references are given which should be followed for further information. The Oil \& Gas Journal articles are a useful source and these often give further references to conference proceedings and articles published in the academic literature. As well as technical articles, Hydrocarbon Processing produces reviews of technology on a regular basis. Nowadays, these are issued on a CD ROM and provide more details of different technologies from the various process licensors.

In the descriptions of the various technologies, several assumptions and omissions to the process flow sheets have been made in order to help understanding of the principal issues and to improve the clarity of the descriptive. If a particular technology or approach is of interest to the reader then the process licensor should be approached for the latest updates and information.

For many chemicals reporting agencies such as ICIS-LORS and Platts produce daily price and volume bulletins for subscribers. ICISLORS data is reported for a wide range of chemicals regularly in ICIS Chemical Business (formerly European Chemical News). Other groups such as Chemical Market Associates regularly report on global trends and prices which are often reviewed in the Oil \& Gas Journal. ${ }^{4}$ 
Purvin \& Gertz Inc. produce regular reports concerning the LPG trade. Some of these reports are reviewed in the Oil \& Gas Journal. ${ }^{5}$

Oil statistics, natural gas and propane prices are readily available from the US Energy Information Administration website (www.eia.gov) which as well collating a vast amount of current and historical data offers useful links to other sites.

\footnotetext{
${ }^{1}$ See also P.B. McIntire, Oil \& Gas Journal, Aug 13, 2001, p. 30

${ }^{2}$ For example D. Lippe, Oil \& Gas Journal, Jul. 7, 2008, p. 64; idem., Nov. 3, 2008, p. 54

${ }^{3}$ K. Weissermel and H.-J. Arpe, "Industrial Organic Chemistry", VCH Publishers, New York, $2^{\text {nd }}$ edition 1993

${ }^{4}$ For example M. Eramo, Oil \& Gas Journal, Dec. 5, 2005, p. 52 and see also ibid., Aug. 25, 2008, p. 48

${ }^{5}$ For example W. Hart, R. Gist, K. Otto. D. Rogers, Oil \& Gas Journal, Jun 23, 2008, p. 58
} 


\section{CONTENTS}

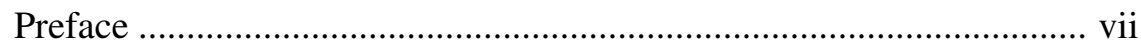

Chapter 1: World Ethylene Production by Steam Cracking ................... 1

North America ...................................................................... 2

European Union and Russia ....................................................... 6

Ethylene Production in the Middle East ..................................... 10

Cracking Operations in the Far East ......................................... 12

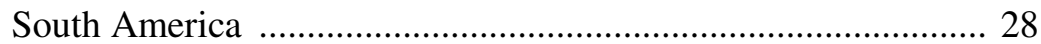

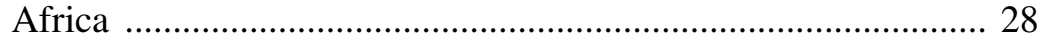

Feedstock and Carbon Emissions .............................................. 29

Chapter 2: Chemistry of Olefin Production .......................................... 33

Thermodynamics of Thermal Cracking ……………………....... 34

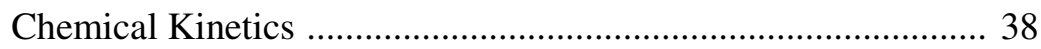

Yield of Ethylene and Propylene from Lighter Feedstock ......... 41

Thermal Cracking of Larger Molecules ........................................ 43

Reaction Severity ......................................................................4 4

Differences between Pyrolysis and Catalytic Cracking .............. 48

Chapter 3: Gaseous Feedstocks - Production and Price …………….... 51

Gaseous Feed Stocks from Natural Gas ……………………....... 51

LPG from Other Sources - LPG Quality ...................................... 63

Prices of Gaseous Feed Stocks ………………………………...... 66

Chapter 4: Liquid Feedstock, Production and Price ………………….... 71

Primary Refinery Operations .................................................... 71

Naphtha Quality …………………………………………..... 75

Price of Naphtha and Other Liquid Feed Stocks ....................... 78 
Chapter 5: Value of Products, Storage and Transport .......................... 87

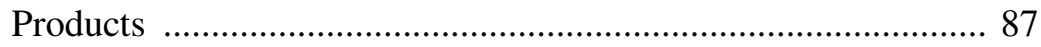

Hydrocarbon By-Products .................................................... 88

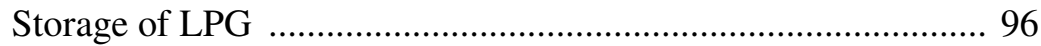

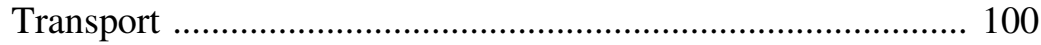

Estimation of Chemical Shipping Costs ................................ 102

Chapter 6: Carbon Dioxide Emissions ................................................. 109

Carbon Geo-Sequestration ................................................ 109

Removal of Carbon Dioxide from Process Streams ................ 110

Removal of Carbon Dioxide from Flue Gas .......................... 115

Strategies for Reducing Carbon Emissions .............................. 117

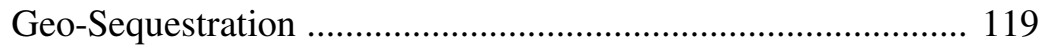

The Cost of Carbon Geo-Sequestration ................................. 121

ECONOMIC ANALYSIS ....................................................... 123

Chapter 7: Ethane Cracking ........................................................ 125

Feed Requirements and Thermal Efficiency .......................... 128

Ethylene Production Costs From Ethane ............................... 131

Carbon Emissions from Ethane Cracking ............................. 141

Chapter 8: LPG Cracking ......................................................... 145

Basic Chemistry of LPG Cracking ...................................... 145

Economics of Propane Cracking ............................................ 147

Economics of Butane Cracking .............................................. 152

Isobutane Cracking ................................................................ 155

Carbon Dioxide Emissions in LPG Cracking ........................ 156

Chapter 9: Liquid Feedstock Cracking ............................................ 159

Economics of Naphtha Cracking .......................................... 161

Gas Oil Cracking ........................................................... 171

Carbon Emissions from Naphtha and LSWR Cracking ........... 175

Chapter 10: Other Routes to Olefins from Hydrocarbons .................. 179

Fluid Cat-Cracking (FCC) ............................................... 179 
Catalytic Cracking to Produce Ethylene .................................. 185

Catalytic Dehydration of Paraffin to Light Olefins ................. 187

Olefin Metathesis ..................................................................... 194

Catalytic Dehydration of Ethanol ......................................... 195

Carbon Emissions from Propane Dehydrogenation .................. 198

Chapter 11: Routes to Olefins from Coal ........................................... 201

Coal to Olefins - Current Technology ..................................... 202

Economics of Olefin Production from Coal and Gas .............. 219

Coal to Acetylene and Olefins ............................................... 222

Carbon Emissions for Gas and Coal to Olefins ....................... 223

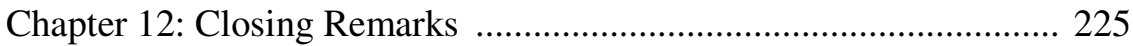

Production Economics ........................................................ 225

Carbon Emissions ….......................................................... 226

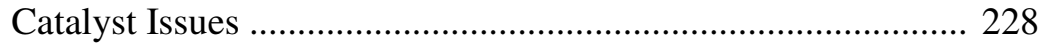

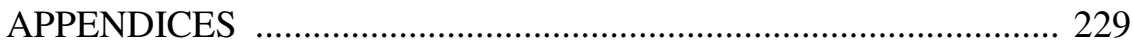

A1: Abbreviations and Unit Equivalents ............................... 231

A2. Some Useful Conversion Factors for Fuels and Products .. 233

A3. Cost of Utilities ............................................................ 235

A4. Nelson-Farrar Cost Indices ........................................... 235

A5. Location Factors ........................................................... 237

A6. Methodology for Economic Analysis ............................. 237

A7. Indexed Feedstock Costs ................................................... 243

Index 